\title{
AL-QUR'AN AND HUMAN MIND: The Facts of Science Development
}

\author{
Prima Aswirna \& Reza Fahmi \\ Institut Agama Islam Negeri (IAIN) Imam Bonjol, Padang \\ e-mail: rfahmi870@gmail.com
}

\begin{abstract}
The scientific facts claimed in the Qur'an are found in different discorces, including in the terms of creation, astronomy, human reproduction, oceanology, embroyology, zoology, and water cycle. This article explored the miracle of alQur'an on scientific knowledge, especially natural science. Applying the approach of descriptive analysis, this study was able to demonstrate the empirical facts about the miracle of al-Qur'an that have been discovered the scientific truth in science. This article also showed the limitations of human intellect to understand all the realities existing in this world, as well as advocated human beings on the importance of returning dialoging al-Qur'an and intellect in exploring science.

Fakta-fakta ilmiah yang diklaim dalam al-Qur'an ada di berbagai wacana, termasuk dalam hal ini penciptaan, astronomi, reproduksi manusia, oseanologi, embroyologi, zoologi, dan siklus air. Artikel ini ingin mengeksplorasi tentang keajaiban al-Qur'an dalam pengetahuan ilmiah, terutama dalam ilmu alam. Dengan pendekatan analisis deskriptif, penelitian ini mampu menunjukkan fakta empiris keajaiban al-Qur'an telah ditemukan kebenaran ilmiah dalam ilmu. Artikel ini juga menunjukkan keterbatasan kecerdasan manusia untuk memahami semua realitas yang ada di dunia ini. Serta mengajak kembali kepada manusia pentingnya untuk kembali mendialogkan antara al-Qur'an dan kecerdasan dalam mengeksplorasi ilmu pengetahuan.
\end{abstract}

Keywords: al-Qur'an, human beings, empirical facts, sciences 


\section{A. Pendahuluan}

Keajaiban al-Qur'an merupakan sebuah fakta ilmiah yang tidak dapat dibantah lagi sebagai sebuah kebenaran. Hal ini telah dibuktikan oleh temuantemuan dalam bidang sains yang pada akhirnya menyimpulkan keajaiban tersebut telah memberikan banyak faedah dan implikasi besar dalam pengembangan ilmu pengetahuan dan teknologi. Sungguhpun demikian masih banyak keajaiaban al-Qur'an lain yang masih menjadi misteri, karena sehakikinya nalar manusia adalah terbatas dalam memahami perubahan alam semesta ini.

Lebih jauh artikel ini akan membahas keajaiban al-Qur'an yang sesungguhnya telah dikaji dalam perspektif ilmu sains. Kemudian adanya keterbatasan nalar manusia dalam memahami keajaiban al-Qur'an itu sendiri. Sehingga kemajuan sains yang diagung-agungkan oleh manusia sebagai wujud peradaban yang seolah-olah sangat maju (so-called: modern). Sedangkan disudut lain alQur'an telah membahas fenomena atau gejala alam tersebut beratus tahun lalu. Disinilah pada akhirnya para pemikir sains kemudian tunduk dan bertafakur serta percaya bahwa ternyata al-Qur'an sebagai sumber ilmu telah memberitahukan peristiwa yang sebelumnya belum pernah terungkap oleh ilmu pengetahuan.

Dengan demikian sungguhpun manusia telah memiliki otak yang dianggap "super canggih" mampu menghasilkan barang dan jasa yang dapat mempermudah dan melayani seluruh kebutuhan hidup mereka. Namun kemampuan otak atau nalar manusia senyatanya juga memiliki limitasi untuk menjelaskan semua tanda-tanda alam. Ini bermakna bahwa kehadiran manusia sebagai insan adalah tidak sempurna.

Melihat realitas tersebut sebagai manusia seharusnya tidak perlu menyikapinya secara pesimis dengan pasrah menerima segala keadaan tanpa berusaha untuk mencari jawaban. Namun sebaliknya, sebagai manusia kita dituntut untuk terus menggali dan mencari ilmu pengetahuan melalui kajiankajian ilmiah, dengan tidak lupa mendalami al-Qur'an sebagai bentuk keyakinan terhadap kebenaran yang terkandung di dalamnya serta keyakinan kita bahwa al-Qur'an sesungguhnya merupakan sumber dan petunjuk bagi manusia dalam memahami ilmu pengetahuan yang diciptakan oleh Allah SWT. 


\section{B. Beberapa Fakta Empiris}

Pada bagian ini akan dijelaskan bukti keajaiban al-Qur'an yang telah ditemukan kebenaran ilmiahnya dalam bidang sains, diantaranya adalah sebagai berikut:

\section{Lapisan-lapisan Atmosfir}

Satu fakta tentang alam semesta sebagaimana dinyatakan dalam al-Qur'an adalah bahwa langit terdiri atas tujuh lapis.

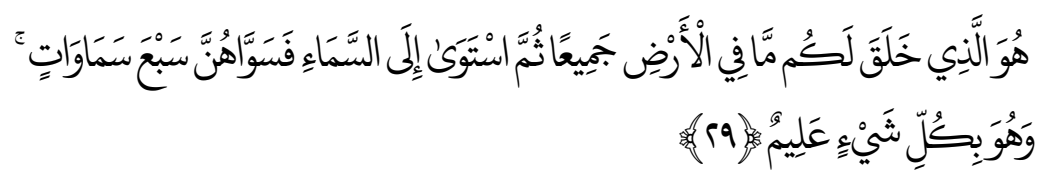

"Dia-lah Allah, yang menjadikan segala yang ada di bumi untuk kamu dan Dia berkehendak menuju langit, lalu dijadikan-Nya tujuh langit. Dia Maha Mengetahui segala sesuatu." 1

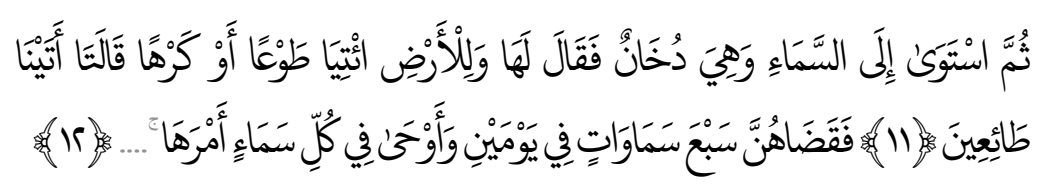

"Kemudian Dia menuju langit, dan langit itu masih merupakan asap. Maka Dia menjadikannya tujuh langit dalam dua masa dan Dia mewahyukan pada tiap-tiap langit urusannya." 2

Kata "langit", yang kerap kali muncul di banyak ayat dalam al-Qur'an, digunakan untuk mengacu pada "langit" bumi dan juga keseluruhan alam semesta. Dengan makna kata seperti ini, terlihat bahwa langit bumi atau atmosfer terdiri dari tujuh lapisan. Saat ini benar-benar diketahui bahwa atmosfir bumi terdiri atas lapisan-lapisan yang berbeda yang saling bertumpukan. Lebih dari itu, persis sebagaimana dinyatakan dalam al-Qur'an, atmosfer terdiri atas tujuh lapisan. Dalam sumber ilmiah, hal tersebut diuraikan sebagai berikut:Para ilmuwan menemukan bahwa atmosfer terdiri diri beberapa lapisan. Lapisan-lapisan tersebut berbeda dalam ciri-ciri fisik, seperti tekanan dan jenis gasnya. Lapisan atmosfer yang terdekat dengan bumi disebut

${ }^{1}$ QS. al-Baqarah [2]: 29.

${ }^{2}$ QS. Fuhshilat [41]: 11-12.

Walisongo, Volume 23, Nomor 2, November 2015 
troposfer. Ia membentuk sekitar $90 \%$ dari keseluruhan massa atmosfer. Lapisan di atas troposfer disebut stratosfer. Lapisan ozon adalah bagian dari stratosfer di mana terjadi penyerapan sinar ultraviolet. Lapisan di atas stratosfer disebut mesosfer. termosfer berada di atas mesosfer. Gas-gas terionisasi membentuk suatu lapisan dalam termosfer yang disebut ionosfer. Bagian terluar atmosfer bumi membentang dari sekitar $480 \mathrm{~km}$ hingga $960 \mathrm{~km}$. Bagian ini dinamakan eksosfer. ${ }^{3}$

Jika kita hitung jumlah lapisan yang dinyatakan dalam sumber ilmiah tersebut, kita ketahui bahwa atmosfer tepat terdiri atas tujuh lapis, seperti dinyatakan dalam ayat tersebut: a) Troposfer. b) Stratosfer. c) Ozonosfer. d) Mesosfer. e) Termosfer. f) Ionosfer. g) Eksosfer. Keajaiban penting lain dalam hal ini disebutkan dalam surat Fushshilat ayat 12.

Dengan kata lain, Allah dalam ayat ini menyatakan bahwa Dia memberikan kepada setiap langit tugas atau fungsinya masing-masing. Sebagaimana dapat dipahami, tiap-tiap lapisan atmosfir ini memiliki fungsi penting yang bermanfaat bagi kehidupan umat manusia dan seluruh makhluk hidup lain di Bumi. Setiap lapisan memiliki fungsi khusus, dari pembentukan hujan hingga perlindungan terhadap radiasi sinar-sinar berbahaya; dari pemantulan gelombang radio hingga perlindungan terhadap dampak meteor yang berbahaya. Salah satu fungsi ini, misalnya, dinyatakan dalam sebuah sumber ilmiah sebagaimana berikut: Atmosfir bumi memiliki 7 lapisan. Lapisan terendah dinamakan troposfir. Hujan, salju, dan angin hanya terjadi pada troposfir. ${ }^{4}$ Adalah sebuah keajaiban besar bahwa fakta-fakta ini, yang tidak mungkin ditemukan tanpa teknologi canggih abad ke-20, secara jelas dinyatakan oleh al-Qur'an 1.400 tahun yang lalu.

\section{Fungsi Gunung}

Al-Qur'an mengarahkan perhatian kita pada fungsi geologis penting dari gunung.

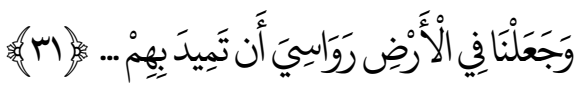
322.

${ }^{3}$ Sheets, Carolyn. et.al. General Science, (Allyn and Bacon Inc. Newton: Massachusetts, 1985), p. 319-

${ }^{4}$ Lihat http://muttley.ucdavis.edu/, diakses 10 November 2015. 
"Dan telah Kami jadikan di bumi ini gunung-gunung yang kokoh supaya bumi itu (tidak) goncang bersama mereka..." 5

Sebagaimana terlihat, dinyatakan dalam ayat tersebut bahwa gununggunung berfungsi mencegah goncangan di permukaan bumi.

Kenyataan ini tidaklah diketahui oleh siapapun di masa ketika al-Qur'an diturunkan. Nyatanya, hal ini baru saja terungkap sebagai hasil penemuan geologi modern. Menurut penemuan ini, gunung-gunung muncul sebagai hasil pergerakan dan tumbukan dari lempengan-lempengan raksasa yang membentuk kerak bumi. Ketika dua lempengan bertumbukan, lempengan yang lebih kuat menyelip di bawah lempengan yang satunya, sementara yang di atas melipat dan membentuk dataran tinggi dan gunung. Lapisan bawah bergerak di bawah permukaan dan membentuk perpanjangan yang dalam ke bawah. Ini berarti gunung mempunyai bagian yang menghujam jauh ke bawah yang tidak kalah besarnya dengan yang tampak di permukaan bumi.

Dalam tulisan ilmiah, struktur gunung digambarkan sebagai berikut: pada bagian benua yang lebih tebal, seperti pada jajaran pegunungan, kerak bumi akan terbenam lebih dalam ke dalam lapisan magma. ${ }^{6}$ Dalam sebuah ayat, peran gunung seperti ini diungkapkan melalui sebuah perumpamaan sebagai "pasak":

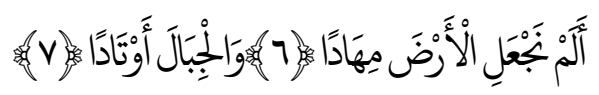

"Bukankah Kami telah menjadikan bumi itu sebagai hamparan?, dan gunung-gunung sebagai pasak?" 7

Dengan kata lain, gunung-gunung menggenggam lempengan-lempengan kerak bumi dengan memanjang ke atas dan ke bawah permukaan bumi pada titik-titik pertemuan lempengan-lempengan ini. Dengan cara ini, mereka memancangkan kerak bumi dan mencegahnya dari terombang-ambing di atas lapisan magma atau di antara lempengan-lempengannya. Singkatnya, kita dapat menyamakan gunung dengan paku yang menjadikan lembaranlembaran kayu tetap menyatu.

Fungsi pemancangan dari gunung dijelaskan dalam tulisan ilmiah dengan istilah "isostasi". Isostasi bermakna sebagai berikut: isostasi: kesetimbangan

${ }^{5}$ QS. al-Anbiya' [21]: 31.

${ }^{6}$ Sheets, Carolyn. et.al. General Science, h. 305.

${ }^{7} \mathrm{QS}$. al-Naba' [78]: 6-7. 
dalam kerak bumi yang terjaga oleh aliran materi bebatuan di bawah permukaan akibat tekanan gravitasi. 8

\section{Lautan yang tidak Bercampur Satu Sama Lain}

Selanjutnya salah satu di antara sekian sifat lautan yang baru-baru ini ditemukan adalah berkaitan dengan ayat al-Qur'an sebagai berikut:

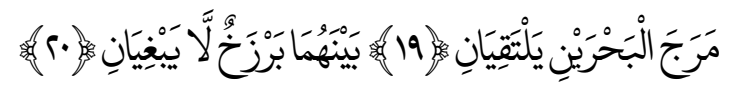

"Dia membiarkan dua lautan mengalir yang keduanya kemudian bertemu, antara keduanya ada batas yang tidak dapat dilampaui oleh masingmasing."

Sifat lautan yang saling bertemu, akan tetapi tidak bercampur satu sama lain ini telah ditemukan oleh para ahli kelautan baru-baru ini. Dikarenakan gaya fisika yang dinamakan "tegangan permukaan", air dari laut-laut yang saling bersebelahan tidak menyatu. Akibat adanya perbedaan masa jenis, tegangan permukaan mencegah lautan dari bercampur satu sama lain, seolah terdapat dinding tipis yang memisahkan mereka. ${ }^{10}$ Sisi menarik dari hal ini adalah bahwa pada masa ketika manusia tidak memiliki pengetahuan apapun mengenai fisika, tegangan permukaan, ataupun ilmu kelautan, hal ini dinyatakan dalam al-Qur'an.

\section{Besi}

Besi adalah salah satu unsur yang dinyatakan secara jelas dalam al-Qur'an. Dalam Surat Al Hadiid, yang berarti “besi”, kita diberitahu sebagai berikut:

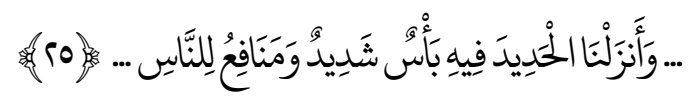

“... dan Kami turunkan besi yang padanya terdapat kekuatan yang hebat dan berbagai manfaat bagi manusia ...." 11

\footnotetext{
${ }^{8}$ Lihat Webster's New Twentieth Century Dictionary, 2. edition "Isostasy", New York, h. 975.

${ }^{9}$ QS. al-Rahman [55]: 19-20.

${ }^{10}$ Davis, Richard A, Jr. Principles of Oceanography, (Don Mills, Ontario, Addison-Wesley Publishing, 1972), h. 92-93.

${ }^{11}$ QS. al-Hadid [57]: 25.
} 
Kata "anzalnā" yang berarti "kami turunkan" khusus digunakan untuk besi dalam ayat ini, dapat diartikan secara kiasan untuk menjelaskan bahwa besi diciptakan untuk memberi manfaat bagi manusia. Tapi ketika kita mempertimbangkan makna harfiah kata ini, yakni "secara bendawi diturunkan dari langit", kita akan menyadari bahwa ayat ini memiliki keajaiban ilmiah yang sangat penting. Ini dikarenakan penemuan astronomi modern telah mengungkap bahwa logam besi yang ditemukan di bumi kita berasal dari bintangbintang raksasa di angkasa luar.

Logam berat di alam semesta dibuat dan dihasilkan dalam inti bintangbintang raksasa. Akan tetapi sistem tata surya kita tidak memiliki struktur yang cocok untuk menghasilkan besi secara mandiri. Besi hanya dapat dibuat dan dihasilkan dalam bintang-bitang yang jauh lebih besar dari matahari, yang suhunya mencapai beberapa ratus juta derajat. Ketika jumlah besi telah melampaui batas tertentu dalam sebuah bintang, bintang tersebut tidak mampu lagi menanggungnya, dan akhirnya meledak melalui peristiwa yang disebut "nova" atau "supernova". Akibat dari ledakan ini, meteor-meteor yang mengandung besi bertaburan di seluruh penjuru alam semesta dan mereka bergerak melalui ruang hampa hingga mengalami tarikan oleh gaya gravitasi benda angkasa. Semua ini menunjukkan bahwa logam besi tidak terbentuk di bumi melainkan kiriman dari bintang-bintang yang meledak di ruang angkasa melalui meteor-meteor dan "diturunkan ke bumi", persis seperti dinyatakan dalam ayat tersebut: Jelaslah bahwa fakta ini tidak dapat diketahui secara ilmiah pada abad ke-7 ketika al-Qur'an diturunkan.

\section{Relativitas Waktu}

Kini, relativitas waktu adalah fakta yang terbukti secara ilmiah. Hal ini telah diungkapkan melalui teori relativitas waktu Einstein di tahun-tahun awal abad ke-20. Sebelumnya, manusia belumlah mengetahui bahwa waktu adalah sebuah konsep yang relatif, dan waktu dapat berubah tergantung keadaannya. Ilmuwan besar, Albert Einstein, secara terbuka membuktikan fakta ini dengan teori relativitas. Ia menjelaskan bahwa waktu ditentukan oleh massa dan kecepatan. Dalam sejarah manusia, tidak seorang pun mampu mengungkapkan fakta ini dengan jelas sebelumnya. Tapi ada perkecualian; al-Qur'an telah berisi informasi tentang waktu yang bersifat relatif! Sejumlah ayat yang mengulas hal ini adalah: 


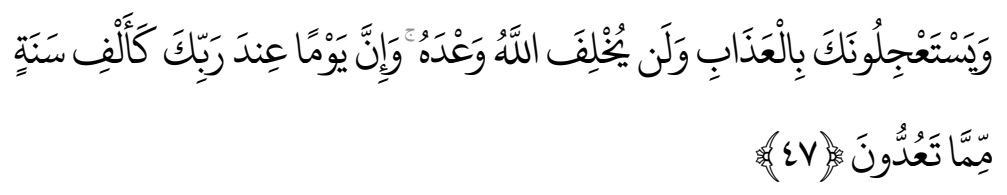

"Dan mereka meminta kepadamu agar azab itu disegerakan, padahal Allah sekali-kali tidak akan menyalahi janji-Nya. Sesungguhnya sehari di sisi Tuhanmu adalah seperti seribu menurut perhitunganmu." 12

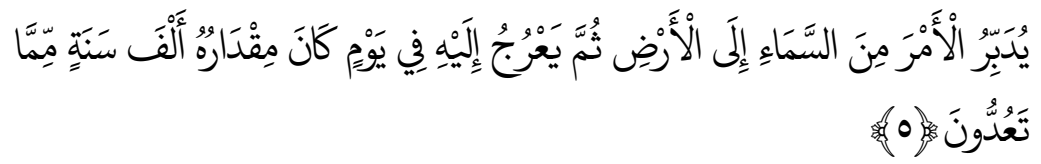

"Dia mengatur urusan dari langit ke bumi, kemudian (urusan) itu naik kepada-Nya dalam satu hari yang kadarnya adalah seribu tahun menurut perhitunganmu." 13

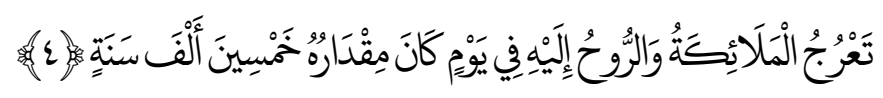

"Malaikat-malaikat dan Jibril naik (menghadap) kepada Tuhan dalam sehari yang kadarnya limapuluh ribu tahun." 14

Semua fakta di atas menunjukkan bahwa relativitas waktu disebutkan dengan sangat jelas dalam al-Qur'an, yang mulai diturunkan pada tahun $610 \mathrm{M}$, adalah bukti lain bahwa al-Qur'an adalah Kitab Suci. Maurice Bucaille ${ }^{15}$ seorang dokter ahli bedah Perancis yang melakukan penelitian ilmiah dalam bidang science telah menegaskan pembuktian keabsolutan kebenaran al-Qur'an. Temuannya yang kemudian diterbitkan dalam buku yang berjudul The Bible, The Qur'an, and Science, menjadi rujukan penting para ahli yang mengkaji ayatayat ilmiah di dalam al-Qur'an.

\section{Manusia sebagai Makhluk Terbatas}

Manusia sebagai makhluk yang serba terbatas (relativismus uber alles), suka ataupun tidak, memerlukan tempat bergantung yang sejatinya ber-

\footnotetext{
${ }^{12}$ QS. al-Hajj [22]: 47.

${ }^{13} \mathrm{QS}$. al-Sajdah [32]:5.

${ }^{14} \mathrm{QS}$. al-Ma'arij [70]: 4.

15Bucaille, Maurice, The Bible, The Qur'an, and Science, (Seattle: Create Space Independent Publishing Platform, 2013) h. 120-125.
} 
kedudukan Mahamutlak (absolutivismus uber alles). Hal ini terkait dengan keyakinan agama. Dengan agama (apa pun definisi orang tentang agama), manusia diajak mengarungi, sekaligus merenungi, sisi-sisi terdalam kemanusiaannya untuk menyempurnakan dirinya. Manusia akan selalu berupaya menuju Realitas Tertinggi (the ultimate reality). Kewajiban manusia adalah melakukan perjalanan dari kedudukannya sebagai makhluk menuju kepada Realitas Tertinggi itu (rihlaḥ min 'l-khalq ila al-Haqq).

Dalam konteks di atas, sejarah manusia sesungguhnya tidak pernah sunyi dari para pencari Tuhan. Dengan dorongan religiusitas dan juga spiritualitas, umat manusia selalu melakukan pencarian demi pencarian Tuhan yang sebenarnya. Bagi sebagian orang, agama memang menjadi jawaban. Namun demikian, sejak ratusan atau bahkan ribuan tahun silam, jauh sebelum tampilnya agama-agama formal (di luar Islam) kepermukaan, dunia telah diramaikan oleh para filosof yang selalu terlibat dalam diskursus ketuhanan (teologi); bahkan dalam wacana tentang asal-usul alam semesta (ontologi) dan ilmu pengetahuan (epistemologi). Sebagian dari mereka benar-benar "menemukan" Tuhan. Akan tetapi, sebagian lainnya terlena dalam "igauan" yang tidak jelas ketika mencoba memaksakan diri menjangkau esensi Tuhan yang sesungguhnya. Mereka terlalu jauh mengembara di belantara metafisisme, sehingga tidak sedikit yang masuk ke dalam perangkap skeptisisme, dan bahkan ateisme.

Sementara itu, di kalangan sebagian kaum Muslim saat ini, keyakinan terhadap Allah masih saja dibungkus oleh hal-hal yang dogmatis dan irasional, ataupun hanya merupakan produk warisan turun-temurun. Kondisi ini sering menimbulkan sinkretisme dan eklektisisme dalam pemikiran keagamaan, yang lebih jauh hanya akan melahirkan individu Muslim yang secara geneologis Islam (Muslim KTP), tetapi dari segi perilaku keseharian malah mengaburkan ajaran Islam. Paling banter, sebagai Muslim, mereka hanya menampilkan kesalihan simbolik dan artifisial. Sebab, di sini, kesalihan tidak lagi diukur oleh kerangka yang lebih substansial, yaitu syariat Islam sebagai sebuah totalitas.

Dalam konteks Islam, sikap keberagamaan demikian tentu saja kontraproduktif, sekaligus kontradiktif, dengan semangat al-Qur'an yang selalu memerintahkan manusia untuk mendasarkankeimanannya pada rasio ('aql) dalam makna yang sesungguhnya; bukan sebatas dorongan intuisi keberagamaan an sich, sebagai representasi dari religiusitas (gharizah al-tadayyūn) 
yang ada pada dirinya. Apalagi jika keimanannya hanyalah produk dari prasangka-prasangka teologis belaka. Sebab keimanan (akidah) itu sendiri, dalam Islam, sejatinya adalah "pembenaran yang pasti (tanpa ada keraguan sedikit pun), yang sesuai dengan realitas (bukan ide khayalan) yang didasarkan pada adanya bukti/dalil (baik dalil 'aqli maupun naqli)."

Oleh karena itu, hanya dengan menggabungkan keduanya, yakni religiusitas (fitrah keberagamaan) dan rasionalitas (pemikiran) -yang tentu saja harus berupa pemikiran yang tercerahkan (al-fikr al-mustanir) - keimanan yang hakiki dan kokoh dapat diraih oleh seorang Muslim. Dalam konteks ini pula, upaya-upaya manusia untuk meretas "Jalan Keimanan" (țāriq al-īmān) yang dikomandani rasio ('aql) akan selalu menemukan relevansi dan signifikansinya.

Perjalanan manusia di dalam realitas kehidupan ini akan selalu dikendalikan oleh suatu "pandangan dunia" (weltanchauung) yang diyakininya. Pandangan dunia manusia pada prinsipnya akan selalu terkait dengan tiga simpul besar ('uqdah al-qubrā) yang beribu-ribu tahun silam dicoba dipecahkan oleh manusia. Simpul besar itu secara ringkas terkait dengan pertanyaan: (1) Darimana manusia berasal? (2) Untuk apa manusia hidup? dan (3) Akan ke mana manusia setelah mati?

Selintas, ketiga pertanyaan tersebut terkesan sangat sederhana. Akan tetapi, upaya pencarian jawaban dari ketiganya ternyata telah menguras tenaga dan pikiran banyak cendekiawan, filosof, ataupun ulama sejak lama. Mereka baik hanya dengan mengandalkan kapasitas intelektual maupun spiritualnya, ataupun dengan melandaskannya pada "wahyu" dari Tuhan- telah berhasil memberikan jawaban atas ketiga persoalan mendasar itu; terlepas dari benartidaknya jawaban tersebut. Jawaban itulah yang sebetulnya menjadi "pandangan dunia" manusia, yang menjadi landasan (rel) bagi dirinya dalam menempuh perjalanan kehidupannya, dan sekaligus menjadi lokomotif yang menarik "gerbong" yang bernama manusia ke arah mana saja yang dia kehendaki.

Secara sederhana, ada tiga gagasan (idea) besar manusia yang memberikan jawaban yang berbeda terhadap ketiga pertanyaan di atas. Pertama, ide yang meyakini bahwa kehidupan dunia ini ada dengan sendirinya (serba kebetulan), dan bukan diciptakan dari ketiadaan (creatio ex nihillo). Manusia berasal dari materi dan akan kembali menjadi materi. Mereka tidak meyakini samasekali adanya Sang Pencipta. Tuhan, menurut mereka, hanya ilusi yang tidak layak dipercaya. Dengan menafikan eksistensi Tuhan, otomatis materi 
dianggap sebagai sesuatu yang azali. Oleh karena itu, tujuan utama manusia hidup pun mesti diorientasikan demi mencari kebahagiaan/kepuasan material di dunia ini. Dalam alam modern, pemahaman demikian direpresentasikan oleh mazhab sosialisme-komunis.

Kedua, ide yang meyakini bahwa seluruh kehidupan di dunia ini berasal (diciptakan) oleh Zat yang Mahamutlak (Tuhan). Akan tetapi, Tuhan tidak lebih dari sekadar "Pembuat Jam". Ia hanya bertugas mencipta, tidak punya orotitas untuk mengatur dan mengendalikan dunia. Manusialah yang memiliki otoritas penuh untuk mengatur dunia dan dirinya sendiri. Di sini, manusia diposisikan sebagai "pusat", sehingga segala sesuatu mesti dikembalikan pada kehendak manusia (antropomorfisme). Agama, dengan demikian, hanya mengisi salah satu ruang kosong yang ada pada batin manusia. Penganut ide ini berkeyakinan bahwa tujuan utama hidup manusia adalah mencapai kebahagiaan yang sepuas-puasnya di dunia (hedonisme). Mereka memang meyakini bahwa manusia akan kembali ke alam akhirat (kepada Tuhan). Akan tetapi, dimensi duniawi dan ukhrawi seolah tidak saling berhubungan. Pemahaman demikian, di alam modern ini direpresentasikan dengan baik oleh penganut mazhab kapitalisme-sekuler.

Ketiga, ide yang meyakini sepenuhnya Tuhan sebagai Sumber dari segala sesuatu (Causa Prima). Manusia diciptakan oleh Tuhan dan akan kembali kepada Tuhan. Oleh karena itu, Tuhanlah yang Azali, sementara selain Tuhan adalah fana (profan). Tuhan juga memiliki otoritas penuh untuk mengatur dunia ini. Manusia hanyalah pelaksana dari aturan-aturan yang telah ditetapkan Tuhan bagi dunia ini. Dengan demikian, di dunia ini tujuan utama hidup manusia harus diorientasikan semata-mata demi mengabdi (ibadah) kepada Tuhan. Bahkan, ibadah merupakan raison d'etre (hakikat terpenting) dari keberadaan manusia sebagai makhluk di hadapan Tuhan sebagai al-Khāliq. Ketaatan atau pengingkaran terhadap kehendak Tuhan di dunia diyakini akan mendapatkan konsekuensi di akhirat (di samping di dunia ini). Dengan demikian, ada keterkaitan erat antara alam dunia dan alam akhirat. Pemahaman seperti ini bersumber sepenuhnya dari konsep teologis Islam sebagai satusatunya agama otentik -baik di masa lalu maupun di masa kini- yang bersumber dari Tuhan yang sebenarnya, yakni Allah SWT.

Dari ketiga gagasan besar yang berbeda yang diberikan oleh masingmasing kelompok manusia di atas, kita akan melihat aturan-aturan hidup yang 
berbeda, yang merupakan derivasi (turunan) dari ketiga gagasan itu. Aturanaturan itu secara niscaya akan menciptakan pola hidup (way of life) yang berbeda pula dari ketiga kelompok masyarakat penganut ketiga gagasan besar tersebut. Ringkasnya, kita akan menyaksikan perbedaan mendasar dari masing-masing kelompok masyarakat yang menganut cara hidup sosialiskomunis, kapitalis-sekuler dan Islam. Agar tidak terjebak pada rasionalisme ekstrim ataupun pemikiran filosofis yang menipu, seorang Muslim selayaknya memahami bahwa meskipun manusia wajib menggunakan rasio (akal)-nya dalam mengimani Tuhan (Allah), tetapi akal manusia memiliki keterbatasan. Untuk itu, memahami hakikat akal adalah penting bagi seorang Muslim.

\section{Kesimpulan}

Memahami keajaiban al-Qur'an harus melalui dua sudut pandang yang holistik- integratif. Di salah satu sisi dibutuhkan pemahaman sains yang komprehensif, yang dengan pemahaman yang komprehensif itu akan menghantarkan manusia untuk memahami fenomena alam. Di sisi lain manusia juga perlu memiliki bekal "Ilmu Keislaman" yang matang, sehingga tanda-tanda keagungan dan kebesaran Allah SWT dapat dipahami sebagai integrasi ilmu agama (Islam) dengan sains secara utuh. Penguasaan sains tanpa agama tidak akan memberikan sumbangsih yang signifikan dalam memahami fenomena kehidupan manusia yang fana. Pada saat yang sama pemahaman agama tanpa sains juga merupakan sebuah ketimpangan pengetahuan. Oleh karenanya islamisasi sains merupakan wujud nyata pengejawantahan pengetahaun tentang keajaiban al-Qur'an itu sendiri. Islamisasi sains harus disadari bukan merupakan upaya ringan. Dibutuhkan kesadaran tinggi mengenai keterbatasan akal dan kemampuan manusia dibandingkan dengan keabsolutan pengetahuan al-Qur'an. Kesadaran inilah yang akan mendorong semangat untuk melakukan kajian serius baik dalam penggalian nilai-nilai yang ada di dalam al-Quran maupun penajaman pengetahuan modern.[w] 


\section{BIBLIOGRAPHY}

Bucaille, Maurice, The Bible, The Qur'an, and Science, Seattle: Create Space Independent Publishing Platform, 2013.

Davis, Richard A., Jr. Principles of Oceanography, Don Mills, Ontario, AddisonWesley Publishing, 1972.

http://www.keajaibanalquran.com/ accessed on November 8th, 2015.

Sheets, Carolyn. et.al. General Science, Allyn and Bacon Inc. Newton, Massachusetts, 1985.

Tafheem-ul-Quran Volume 3, Introduction to Sura Room (Rome), ie Chapter\#30 and the explanation of the first four verses.

Tuncer, "International Conferences on Islam in the Contemporary World", March 4-5, 2006, Southern Methodist University, Dallas, Texas, U.S.A.

Wilson, Christy, "The Qur'an" in A Lion Handbook The World's Religion. 
